\title{
HIV Seropositivity in Patients Admitted to Our Hospital: Six Year Evaluation
}

\author{
Hastanemize Başvuran Hastalardaki HIV Seropozitifliği: Altı Yıllık Değerlendirme
}

\author{
İlkay BAHÇECI' ${ }^{1}$ \\ (i) 0000-0003-3662-1629 \\ İlknur Esen YILDIZ ${ }^{2}$ \\ (D) 0000-0003-2987-0483
}

\begin{abstract}
${ }^{1}$ Recep Tayyip Erdogan University Faculty of Medicine Department of Medical Microbiology, Rize, Turkey ${ }^{2}$ Recep Tayyip Erdogan University Faculty of Medicine Department of Infectious Diseases, Rize, Turkey
\end{abstract}

\section{Corresponding Author Sorumlu Yazar \\ İlkay BAHÇECI \\ bahceciie@hotmail.com}

Received / Geliş Tarihi : 25.12.2020 Accepted / Kabul Tarihi : 03.03.2021 Available Online /

Çevrimiçi Yayın Tarihi : 13.03.2021

\begin{abstract}
Aim: Detecting human immunodeficiency virus (HIV)-infected individuals is very important in terms of quality of patients' lives. However, it should be kept in mind that there may be false positives and tests must be confirmed. In this study, it was aimed to determine HIV seropositivity in our hospital for a period of six years and to contribute to the epidemiological data of the country.

Material and Methods: The samples that came to serology laboratory between January 2014 and December 2019 were analyzed retrospectively. Anti-HIV antibodies were screened in a total of 180,413 samples by the macro-ELISA method (Architect i2000sr, Abbott, USA). Patient samples were sent to the National HIV/AIDS Confirmation and Viral Hepatitis Reference Laboratory for verification of reagents results.

Results: Anti-HIV results of $178(0.1 \%)$ of 180,413 patients whose blood serum samples were studied with the macro-ELISA method were evaluated as reactive. Confirmation test of 102 patients were negative while 76 were positive. Patients with positive confirmation result account for $0.04 \%$ of all patients. While $67(88.2 \%)$ of the patients with positive confirmation were male and $9(11.8 \%)$ were female. The ages of $26-35$ and $36-45$ years were equal with the highest number of new cases detected $(n=20,26.3 \%)$.

Conclusion: As a result of our retrospective evaluation, HIV seropositivity, gender and age distributions in our hospital were found to be compatible with the data of our country and other studies conducted in our country. The high false positivity rate of screening tests, again indicates the importance of confirmation tests.

Keywords: Anti-HIV; ELISA; HIV verification.
\end{abstract}

ÖZ

Amaç: İnsan bağışıklık yetmezliği virüsü (human immundeficiency virüs, HIV) ile infekte bireylerin tespit edilmesi yaşam kalitesi açısından oldukça önemlidir. Ancak yalancı pozitifliklerin olabileceği ve testlerin mutlaka doğrulanması gerçeği unutulmamalıdır. $\mathrm{Bu}$ çalışmada hastanemizdeki altı yıllık süre zarfinda HIV seropozitifliğinin saptanması ve ülke epidemiyolojik verilerine katkı sağlanması amaçlanmıştır.

Gereç ve Yöntemler: Ocak 2014 ve Aralık 2019 tarihleri arasında seroloji laboratuvarına gelen örnekler geriye dönük olarak incelenmiștir. Toplamda 180,413 örnekte makro-ELISA yöntemi ile (Architect i2000sr, Abbott, USA) anti-HIV antikoru taranmıştır. Reaktif gelen sonuçların hasta örnekleri doğrulanmak üzere Ulusal HIV-AIDS Doğrulama ve Viral Hepatitler Referans Laboratuvarı'na gönderilmiştir.

Bulgular: Makro-ELISA yöntemi ile kan serum örnekleri çalışılan 180,413 hastadan 178 $(\% 0,1)$ 'inin anti-HIV sonucu reaktif olarak değerlendirilmiştir. 102 hastanın doğrulama testi negatif iken 76 's1 pozitifti. Doğrulama testi sonucu pozitif olan hastalar tüm tetkik edilen hastaların \%0,04'ünü olușturmuștur. Doğrulama testi sonucu pozitif olan hastaların 67 $(\% 88,2)$ 'si erkek iken $9(\% 11,8)$ 'u ise kadındır. Yaş dağılımı incelendiğinde ise 26-35 yaş ve 36-45 yaş aralıkları eşit oranda olup en fazla $(n=20, \% 26,3)$ yeni vaka tespit edilen yaş aralıkları olmuştur.

Sonuç: Yapılan geriye dönük bu değerlendirmemiz sonucunda, HIV seropozitifliği, cinsiyet ve yaş dağılımlarının ülkemiz verileri ve ülkemizde yapılan diğer çalışmaların verileri ile uyumlu bulunmuştur. Tarama testlerindeki yalancı pozitifliğin oldukça yüksek olması, doğrulama testlerinin ne denli önemli olduğunu bir kez daha hatırlatmıştır.

Anahtar kelimeler: Anti-HIV; ELISA; HIV doğrulama. 


\section{INTRODUCTION}

All around the world and in our country, the number of individuals infected with Human Immunodeficiency Virus (HIV) tends to increase, and the rates are considered to be much higher than those tested. According to the Joint United Nations Program on HIV/AIDS (UNAIDS), it was reported that there were 37.9 million people infected with HIV to date, 1.8 million individuals had been infected with HIV and 770,000 individuals had died due to acquired immunodeficiency syndrome (AIDS) in 2018 (1). In our country, it was found that 19,748 individuals had been infected with HIV since the first case seen in 1985 until the end of 2018 and 1772 of them had progressed to AIDS (2). HIV targets immune system cells, mainly CD4 T lymphocytes. After the virus enters the human body, it leads to clinical manifestations of acute and chronic HIV infection. Unless the individual receives early diagnosis and treatment, AIDS occurs with various concomitant opportunistic infections and malignancies accompanying (3). Two different viral strains, whose nucleotide sequences show $40 \%$ similarity to each other and both of which can progress to the clinical manifestations of AIDS, were isolated all around the world. While HIV-1 is the most common type all over the world, HIV-2 is seen as endemic in West Africa (4).

The virus is transmitted through sexual contact, blood and blood products, vertical transmission from mother to baby, and tissue-organ transplantation. Transmission among healthcare workers can also occur due to their occupational risk. Those who have more than one sexual partner, particularly the male who have sex with male, injecting drug users, babies born from HIV-infected mothers play a major role in viral transmission (5). Recognizing the risk groups and receiving the early diagnosis and treatment are essential in order to ensure the quality of life of individuals and community. In this context, in order to control the HIV epidemic, implementing the 90-90-90 targets (Diagnosing $90 \%$ of HIV-infected people, initiating antiretroviral therapy in $90 \%$ of people diagnosed, providing viral suppression among $90 \%$ of patients who receive antiretroviral therapy) holds great importance for the UNAIDS organization (6).

For disease control, early, accurate and rapid diagnosis and initiation of treatment as soon as possible is the key point in terms of reducing the individual's mortality and morbidity as well as preventing transmission among the community (7).

The aim of this study was to evaluate the anti-HIV seropositivity and the results of confirmation tests in patients admitted to our hospital between 2014 and 2019 and so to contribute to Turkey's epidemiological data.

\section{MATERIAL AND METHODS}

Anti-HIV test results of 180,413 patients, who admitted to Recep Tayyip Erdoğan University Faculty of Medicine Training and Research Hospital and got examined for miscellaneous reasons between the years 2014 and 2019, were retrospectively analyzed. The patients' reagent samples, which were repeatedly detected, were excluded in the study. Regardless of age and sex, anti-HIV test samples from all clinics were included in the study.

The samples delivered to our laboratory were first centrifuged at $4000 \mathrm{rpm}$ for 20 minutes and then serum was obtained. Subsequently, anti-HIV antibody was analyzed by macro-ELISA method using Architect i2000sr Chemiluminescence Microparticle Immunoassay (CMIA; Abbott, USA) System. The kit used, which detects HIV p24 antigen and HIV type 1 (HIV-1 group M and group O) and HIV type-2 antibodies, is a fourth generation. Depending on the manufacturer's recommendations, samples with values below $1 \mathrm{~s} / \mathrm{co}$ were evaluated as 'nonreactive', whereas samples with values of $1 \mathrm{~s} / \mathrm{co}$ and above were considered as reactive. A new sample was requested from the patients whose anti-HIV test results were reactive, and the test was repeated in both samples of the patients. Non-reactive results were reported as nonreactive. The samples which both tests were detected as reactive, were sent to the Republic of Turkey Ministry of Health, General Directorate of Public Health, Department of Microbiology Reference Laboratories and Biological Products, National HIV-AIDS Confirmation and Viral Hepatitis Reference Laboratory for confirmation tests.

Confirmation was performed with the LIA (INNO-LIA TM HIV I/II Score; Innogenetics, Ghent, Belgium) method at the National HIV-AIDS Confirmation and Viral Hepatitis Reference Laboratory. Within this method, the strips in which HIV-1 -and HIV-2- specific recombinant proteins and synthetic peptides, and HIV-1 group O- specific synthetic peptides are replaced are being used. In case of the presence of antibodies against the protein and peptides in the strip of the sample tested, bands are seen.

At the reference center, after the year 2016, although the sample shows ELISA reactivity, in case of indeterminate or negative results taken with LIA, the sample sentare being examined for HIV-1 RNA PCR (artus HI virus-1 RG RT-PCR, Qiagen; Hilden, Germany) in terms of acute HIV infection.

Ethics committee approval for this study was obtained from the Non-Interventional Clinical Research Ethics Committee of Recep Tayyip Erdoğan University Faculty of Medicine (01.10.2020, 209).

\section{Statistical Analysis}

The data were summarized as number and percentage. SPSS v.21.0 statistical package was used for statistical data analysis.

\section{RESULTS}

The mean age of 180,413 patients evaluated in the study was 50 years, $93,598(51.9 \%)$ patients were male and their mean age was 49 years. 86,815 $(48.1 \%)$ patients were female and their mean age was 51 years. When we evaluated the distribution of the tests by years, it was found that the highest rate with 33,449 (18.5\%) was in 2018. The distribution of the number of patients requested tests and test positivity by years were shown in Table 1 . The majority of samples delivered to the laboratory, 21,610 (12\%), was belonged to the gastroenterology clinics. The highest number of positive patients was in 2019 with 20 patients. It was determined that $178(0.1 \%)$ of the patients, whose Anti-HIV antibody was analyzed with macro-ELISA method, were reactive and 180,235 (99.9\%) of them were non-reactive. $112(62.9 \%)$ of the reactive results were of male patients. Infectious Diseases and Clinical Microbiology Outpatient Clinics had the highest number of reactive results with $37(20.8 \%)$ patients. 
Table 1. Distribution of HIV tests by years

\begin{tabular}{lccccc}
\hline Years & Number of patients & Anti-HIV reactive & Anti-HIV non-reactive & $\begin{array}{c}\text { Positive } \\
\text { Confirmation Test }\end{array}$ & $\begin{array}{c}\text { Negative } \\
\text { Confirmation Test }\end{array}$ \\
\hline 2014 & 27727 & 23 & 27704 & 10 & 13 \\
2015 & 27263 & 30 & 27233 & 6 & 24 \\
2016 & 30213 & 23 & 30190 & 10 & 13 \\
2017 & 31331 & 29 & 31302 & 16 & 13 \\
2018 & 33449 & 38 & 33411 & 20 & 24 \\
2019 & 30430 & 35 & 30395 & 76 & 15 \\
\hline Total & 180413 & 178 & 180235 & & 102 \\
\hline
\end{tabular}

For confirmation tests, $102(57.3 \%)$ of the samples sent to the National HIV/AIDS Confirmation and Viral Hepatitis Reference Laboratory were negative, and 76 (42.7\%) of them were positive. Patients with positive confirmation test results comprised $0.04 \%(n=76)$ of all patients (Table 2). As $67(88.2 \%)$ of the positive patients were male, the majority of these individuals consisted of 28 (36.8\%) patients followed at the Infectious Diseases and Clinical Microbiology Outpatient Clinics. The highest number of false reactive patients was detected to be at the Internal Medicine Clinic with 10 (9.8\%) patients. The distribution of positive patients by clinics was shown in Figure 1. While the mean age of patients with positive confirmation tests was 41.5 years, the age range of the patients was between 18-81 years. When we analyzed the age distribution of infected individuals, it was found that the age groups of 26-35 years and 36-45 years had equal percentages and the highest number of newly detected cases with $26.3 \% \quad(n=20)$ were belong to this ranges (Figure 2). As the results of macro-ELISA method were examined according to the confirmation tests, the lowest Anti-HIV value as true reactive was determined as 9.36 s/co, and the highest Anti-HIV value as false reactive was determined as $173.92 \mathrm{~s} / \mathrm{co}$.

$\underline{\text { Table 2. Confirmation test results of anti-HIV reactive samples }}$

\begin{tabular}{llcc}
\hline & & \multicolumn{2}{c}{ Macro-ELISA Test Results } \\
\cline { 3 - 4 } & & Reactive & Non-reactive \\
\hline Confirmation & Positive & $76(0.04 \%)$ & - \\
Test Results & Negative & $102(0.05 \%)$ & $180235(99.9 \%)$ \\
\hline & Total & $178(0.1 \%)$ & $180235(99.9 \%)$ \\
\hline
\end{tabular}

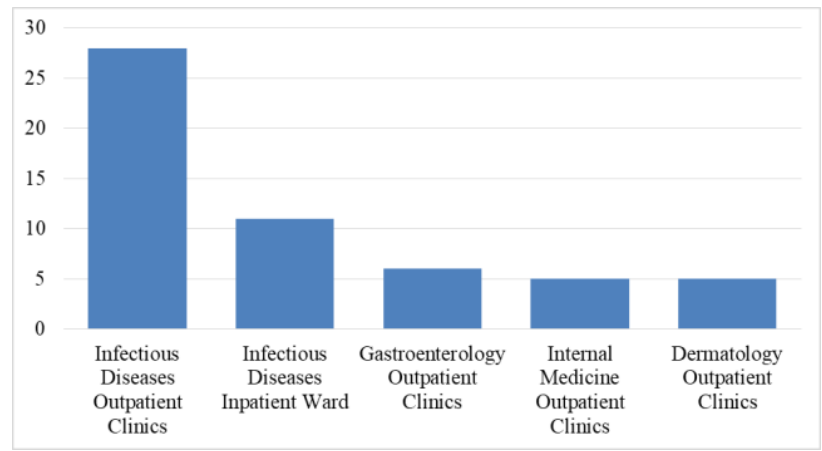

Figure 1. Distribution of HIV-positive patients by clinics

\section{DISCUSSION}

Despite all the progress made and all the measures taken, HIV infection and clinical presentation of AIDS continue to seem as a serious public health problem all over the world, particularly in developing countries. According to UNAIDS data, while $61 \%$ of the newly infected people with HIV were from Sub-Saharan African countries, African countries constitute the largest group with 25.7 million infected people worldwide in 2018 (1). It is very important to have information about the epidemiological data at country level in order to determine the shortcomings and to take the necessary measures. Additionally, early initiation of treatment by diagnosing individuals can increase the quality of life and contribute to the countries' level of development. In this context, our aim to make contribution to medical literature by presenting our own data.

Serological methods are used most frequently for the diagnosis of HIV infection, whereas ELISA method is used as screening test, and Indirect Immune Fluorescent Antibody Test (IFA), Line-Immunoassay (LIA), Western Blot, and HIV-1/2 antibody differentiating rapid confirmation tests are used as confirmation tests (4). In recent years, fourth generation combo tests, which detect the p24 antigen that emerge approximately one week before antibodies exist, have become routine as screening tests, besides HIV antibodies (7). Western Blot has been commonly performed as confirmation test, but it has been replaced by HIV-1/2 antibody differentiating rapid confirmation tests in the world and in our country due to its low sensitivity rate, excess of cross-reactions and demanding test properties.

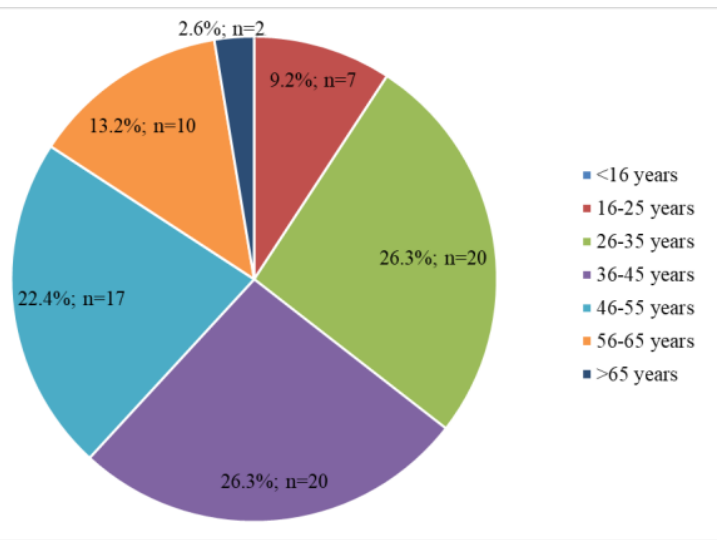

Figure 2. Distribution of HIV confirmed positive patients by age 
Although the most common cause of HIV transmission worldwide is sexual transmission, the leading cause of transmission is homosexual contact in developed countries and heterosexual contact in underdeveloped countries (5). According to our country data, heterosexual sexual transmission ranks first among HIV-infected individuals (2). The study data were evaluated retrospectively, and the fact that transmission routes were not reached from epidemiological data is one of the limitations of this study. In some studies conducted in Turkey, as the distribution by gender are examined, it was found that HIV seropositive patients with rates varying between $75.5 \%$ and $84.7 \%$ mostly consisted of male patients $(6,8-19)$. In our study, $62.9 \%$ of HIV seropositive patients were male in majority, as in other studies. It has been reported worldwide that there are 18.8 million female and 17.4 million male patients, making female patients proportionally higher. This may be due to social reasons since as our country has a male-dominated society.

As the studies conducted in Turkey are evaluated without selecting a particular group, HIV seropositivity rate was found to be $0.04 \%$ and $0.08 \%$, respectively, in two different studies $(8,17)$ conducted in Izmir. In two different studies $(14,18)$ conducted in Ankara, HIV seropositivity rate was $0.087 \%$ and $0.006 \%$, respectively, on the other hand, in a study conducted in Istanbul (19), it was found to be $0.068 \%$. According to the studies conducted in our provinces of Artvin (20), Balıkesir (21), Isparta (22) and Kars (23), HIV seropositivity rate was reported as $0.05 \%$, $0.004 \%, 0.01 \%$, and $0.009 \%$, respectively. We observed that similar results were obtained in other provinces with a HIV seropositivity rate of $0.04 \%$ in our study. Eventhough, the study is one of the first studies evaluating seropositivity in the province of Rize, it should be supported with the other hospitals' data in a way to draw the profile of the entire province.

It is an obvious fact that HIV transmission is higher in certain age groups. Different rates have been reported within studies conducted throughout the country and around the world (24-27). In the data from Ministry of Health, the age group of 25-34 years draws attention as the age group with the most cases (2). This circumstance is considered to be related to the regional location of Rize province. In particular, it suggests that partner transmission should be investigated and relevant measures should be taken.

Confirmation test results with ELISA show differences. In previous studies conducted in Izmir (8), Istanbul (19) and Sakarya (6), the true positivity percentages were determined as $41 \%, 74 \%$, and $68 \%$, respectively. In our study, true HIV positivity was found to be $42 \%$ in antiHIV reactive patients. We suppose that this situation may have stemmed from the unnecessary test requests by the clinicians at our hospital. The fact that the healthcare workers had tests to feel safe, especially during the preinvasive interventions, and the individuals thinking that they carry risk in terms of sexual transmission due to their location. Similarly, it can be explained by the difference between the kits used for analysis, compared to other hospitals. Toptan et al. (6) found the highest value of 13.3 $\mathrm{s} / \mathrm{co}$ as false reactive and the lowest value as true reactive, on the other hand, was found to be $5.29 \mathrm{~s} / \mathrm{co}$. Considering that we detected the lowest value $9.36 \mathrm{~s} / \mathrm{co}$ as true reactive, it was in parallel with the mentioned study. Nevertheless, the highest Anti-HIV value 173.92 s/co, which we found as false reactive differ significantly, compared to Toptan et al.'s (6) study. In this context, attention should be paid to ensuring the controls of laboratory data follow-up by reference centers. In our study, there are limitations such as inability to differentiate between HIV types, unavailability to determine the distribution of transmission routes, and lack of information about the clinical processes of the patients. All the information gives the key points that provide support in the disease control. We consider that more medical studies, in which laboratory data are evaluated in conjunction with clinical aspects, patients are followed up with epidemiological forms, and shortcomings are determined, seem essential.

\section{CONCLUSION}

Surveillance studies conducted are of great importance for disease control. The study is one of the very first studies in which patients were evaluated in relation to HIV infection in the province of Rize, and the study data are largely compatible with other studies carried out throughout our country. However, the study should be assisted by using data from which patients are also clinically evaluated in terms of HIV infection. For all that, we consider that it is critical to remind the correct use of diagnostic tests for the disease, the need to confirm the reactive samples within the screening tests and the fact that unnecessary tests shouldn't be requested.

Ethics Committee Approval: The study was approved by the Ethics Committee of Recep Tayyip Erdoğan University Faculty of Medicine (01.10.2020, 209).

Conflict of Interest: None declared by the authors.

Financial Disclosure: None declared by the authors.

Acknowledgements: The authors would like to thank Ömer Faruk DURAN for his contribution.

Author Contributions: Idea/Concept: İB; Design: İB; Data Collection/Processing: IB; Analysis/Interpretation: İB, İEY; Literature Review: İB, İEY; Drafting/Writing: İB; Critical Review: İB, İEY.

\section{REFERENCES}

1. unaids.org [Internet]. UNAIDS. UNAIDS data 2019. [Cited: 2020 Dec 12]. Available from: https://www.unaids.org/en/resources/documents/2019 /2019-UNAIDS-data

2. hsgm.saglik.gov.tr [Internet]. Republic of Turkey Ministry of Health. Turkey HIV/AIDS control program 2019-2024. [Cited: 2020 Dec 12]. Available from: https://hsgm.saglik.gov.tr/depo/birimler/Bulasicihastaliklar-db/hastaliklar/HIV-ADS/TaniTedavi_Rehberi/HIV_AIDS_Kontrol_Programi.pdf

3. hsgm.saglik.gov.tr [Internet]. Republic of Turkey Ministry of Health. HIV/AIDS diagnostic guide. [Cited: 2020 Dec 12]. Available from: https://hsgm.saglik.gov.tr/depo/birimler/Bulasicihastaliklar-db/hastaliklar/HIVADS/Tani_Klavuzu/HIV-AIDS_Tani_Klavuzu.pdf 
4. hsgm.saglik.gov.tr [Internet]. Republic of Turkey Ministry of Health. HIV/AIDS diagnosis and treatment guide 2019. [Cited: $2020 \mathrm{Dec} 12$ ]. Available from: https://hsgm.saglik.gov.tr/depo/birimler/Bulasicihastaliklar-db/hastaliklar/HIV-ADS/TaniTedavi_Rehberi/HIV_AIDS_Tani_Tedavi_Rehberi_ Yeni.pdf

5. Özkaya Şahin G, Başaran Çalık N, Ünal S. HIV transmission routes and speeds. Türk HIV/AIDS Derg. 2005;8(1):5-12.

6. Toptan H, Aslan FG, Karakeçe E, Aydemir Ö, Demiray T, Köroğlu M, et al. Evaluation of patients with anti-HIV $1 / 2$ reactivity with confirmation test results. J Biotechnol and Strategic Health Res. 2019;3(1):27-32.

7. Aslan FG, Altındiş M. Current diagnostic algorithm of HIV and emerging prevention methods. Türk Mikrobiyol Cem Derg. 2017;47(2):47-60.

8. Şamlıŏ̆lu P, Karaca Derici Y, Yılmaz Hanci S, Doğan G, Bayram A, Agus N, et al. Evaluation of two-year HIV positivity in a tertiary hospital. Turk Hij Den Biyol Derg. 2019;76(4):391-4.

9. Doğaner İB, Tabak FA, Us T. The incidence rate of confirmed real HIV pozitivity in Eskisehir region. T Tıp Öğr Arş D. 2019;1(3):73-7.

10. Güreser AS, Özçelik S, Boyacıŏlu Zİ, Özünel L, Yıldız Ü, Taylan Özkan A. Seropositivity rates of HBsAg, anti-HCV, HIV and VDRL in blood donors in Çorum Turkey. Turk Hij Den Biyol Derg. 2015;72(2):123-30.

11. Şanlı K, Sarı ND, Hatipoğlu N. Evaluation of 10-year screening test result in blood donors consulted to our blood center. JOPP Derg. 2013;5(3):136-41.

12. Bulut N, Yenişehirli G, Bulut Y. Seroprevalence of Hepatitis B, Hepatitis C, HIV and Syphilis in blood donors in Tokat. Viral Hepat J. 2012;18(1):11-4.

13. Gül M, Çıragil P, Aral M, Doğramacı N. The evaluation of $\mathrm{HBV}, \mathrm{HCV}, \mathrm{HIV}$ and syphilis screening test results in voluntary and nonvoluntary blood donors. Türk Mikrobiyol Cem Derg. 2006;36(1):35-9.

14. Gürkan Y, Toyran A, Aksoy A, Coşkun FA, Sezer A. Seroprevalance of Hepatitis and HIV in patients and blood donors and evaluation of HCV-RNA levels in Anti-HCV positive samples in Ankara Numune Training and Research Hospital. Viral Hepat J. 2013;19(3):131-5.

15. Parlak M, Özlük S, Demir C, Rağbetli C. Seroprevalence of HBsAg, Anti-HCV, Anti-HIV and syphilis in blood donors. KÜ Tip Fak Derg. 2015;17(3):1-6.
16. Çelebi D, Çelebi Ö, Altoparlak Ü, Kök AN. Evaluation of HBsAg, Anti-HCV, Anti-HIV $1 / 2$ and syphilis seroprevalence of the blood donors and the comparison of the macro-ELISA optical density values with confirmatory tests. Türk Mikrobiyol Cem Derg. 2012;42(4):137-41.

17. Uzun B, Güngör S, Er H, Pektaş B, Demirci M. Seropositivity rates of $\mathrm{HBsAg}$, Anti-HCV, Anti-HIV in outpatients in İzmir Atatürk Traning and Research Hospital. Viral Hepat J. 2013;19(3):123-5.

18. Özdem B, Çelikbilek N, Açikgöz ZC. Anti-HIV and confirmation test results of our hospital for seven years (2004-2010). Mikrobiyol Bul. 2011;45(3):577-9.

19. Yüksel P, Ziver T, Izmirli S, Aslan M, Sarıbaş S, Güngördü Z, et al. Confirmatory test results in antiHIV-positive patients: Evaluation of five-year data. Klimik Derg. 2010;23(2):51-4.

20. Ínci A, Okay M, Güven D. HBsAg, anti-HBs, antiHCV and anti-HIV seroprevalence of the patients apply to Artvin State Hospital. Viral Hepat J. 2013;19(1):41-4.

21. Şafak B. HBsAg, anti-HCV and anti-HIV seroprevalence of the patients in Balıkesir Atatürk State Hospital. Viral Hepat J. 2013;19(2):43-5.

22. Aynali A, Cicioğlu Arıdoğan B, Nurlu Temel E, Çarsancaklı SA, Sesli Çetin E. HBs Ag, Anti-HCV, Anti-HIV seropositivity rates in samples working in a university hospital laboratory. Genel Tip Derg. 2016;26(4):106-8.

23. Çetinkol Y. HBsAg, Anti-HCV and Anti-HIV seroprevalence of the patients apply to Kars Public Hospital. Viral Hepat J. 2012;18(2):76-80.

24. Dinç HÖ., Özbey D, Sirekbakan S, Gareayaghi N, Kocazeybek BS. Seroepidemiologic evaluation of HIV scanning and verification datas during the period of 2015-2018. ANKEM Derg. 2019;33(3):89-94.

25.hsgm.saglik.gov.tr [Internet]. Republic of Turkey Ministry of Health. HIV/AIDS Statistics. [Cited: 2020 Dec 12]. Available from: https://hsgm.saglik.gov.tr/tr/bulasici-hastaliklar/hivaids/hiv-aids-liste/hiv-aids-istatislik.html

26. who.int [Internet]. World Health Organization. HIV data and statistics. [Cited: 2020 Dec 12]. Available from: https://www.who.int/teams/global-hiv-hepatitisand-stis-programmes/hiv/strategic-information/hivdata-and-statistics.

27. Beka H, Yılmaz M, Köksal MO, Meşe S, Eraksoy H, Somer A, et al. Evaluation of validation test result in anti HIV reactive patients. ANKEM Derg. 2018;32(2):72-7. 